\title{
Implementation of the Concept of Conservation Area Buffer Zone in Indonesia
}

\author{
Salwa Nadhira*, Sambas Basuni \\ Department of Forest Resources Conservation and Ecotourism, Faculty of Forestry and Environment, IPB University, \\ Academic Ring Road Campus IPB Dramaga, Bogor, Indonesia 16680
}

Received January 4, 2021/Accepted March 3, 2021

\begin{abstract}
Conservation area buffer zones are recognized to provide ecological, social, and economic benefits in supporting conservation areas' integrity. Nevertheless, little is known hitherto about the development dynamics of conservation area buffer zones in Indonesia. Therefore, a study concerning theory, policy, and management of the conservation area buffer zones in Indonesia is necessary to analyze its performance, identify problems in its implementation, and formulate its evidence-based development policy. This study aims to identify and analyze issues in implementing the concept of conservation area buffer zone as well as recommend policy formulation to accelerate the development of conservation area buffer zones in Indonesia. This study is an exploratory research through a literature review with semi-systematic approach. It finds that there are only nine out of $530(1.7 \%)$ conservation areas in Indonesia with a formally established buffer zone. This condition is mainly due to the absence of buffer zone institutions at the regional government levels. Meanwhile, the management of supposedly buffer zones has been conducted through various projects for strengthening the functions of buffer zones by conservation area managers, either in the form of landbased or non-land-based projects. This study results in recommendations for all interested parties to urge the Ministry of Environment and Forestry and the Ministry of Home Affairs to promulgate and renew the regulations concerning the procedures of establishing and managing conservation area buffer zones. Moreover, regarding the institutional aspect, there is a need for a particular structure in both ministries to address community empowerment issues at the site level.
\end{abstract}

Keywords: development, institutions, management, policy, empowerment

*Correspondenceauthor,email:salwa_nadhira@apps.ipb.ac.id

\section{Introduction}

The term "buffer zone" became known globally after the launch of Man and Biosphere (MAB) programs by UNESCO in 1971. According to UNESCO (1996), a buffer zone could be in the form of an area surrounding or adjoining a biosphere reserve's core area. The core area could be a protected site for biodiversity conservation, ecosystem disturbances monitoring, non-destructive research, and low-impact use. This definition explains that the buffer zones of Biosphere Reserves, together with their transitional areas, lie outside the boundaries of protected sites, such as conservation areas. This UNESCO definition of a buffer zone, particularly of a buffer zone located outside the core area, has profoundly influenced the implementation of the concept of protected or conservation area buffer zone worldwide (Martino, 2001).

Buffer zones are acknowledged to provide ecological, social, economic, and institutional benefits. The ecological benefits of buffer zones include screening or limiting human access and illegal activities, protecting conservation areas from invasive flora and fauna, and acting as habitat extensions for wide-ranging animals living in the conservation areas. Meanwhile, buffer zones' social benefits include providing flexible conflict resolution mechanisms between conservation and community interests, increasing potential income sources and improving the environmental quality for the local community, and building local community support for conservation activities. Buffer zones also provide economic benefits, including giving local communities opportunities to utilize the direct and indirect use of forest resources and ecosystem services (Sayer, 1991). In the institutional aspect, buffer zones could become the medium to introduce participatory planning methods and conservation area monitoring, and raise awareness of the importance of natural areas for direct and indirect use (Ebregt \& de Greve, 2000). Given the substantial benefits of conservation area buffer zones, in 1990, the Indonesian government promulgated a law that, among others, regulates conservation area buffer zones in Indonesia. However, today the development dynamics of conservation area buffer zones in Indonesia are still not widely known.

Conservation area buffer zones in Indonesia generally consist of two forms of land ownership; state land ownership and private land ownership. As a result, the policy regarding conservation area buffer zones at the central government level falls under two ministries' authority; the Ministry of Home Affairs (Kementerian Dalam Negeri/Kemendagri) 
and the Ministry of Forestry which later became the Ministry of Environment and Forestry (Kementerian Lingkungan Hidup dan Kehutanan/KLHK). Kemendagri works with regional governments that possess the authority to regulate privately owned land and or free state land, while KLHK regulates forest areas located on state-owned land.

Hence, a study concerning the implementation of the concept of conservation area buffer zone in Indonesia is necessary to identify and analyze its problems and recommend policy formulation to accelerate the development of conservation area buffer zones in Indonesia. This study's research questions include: 1) what are the existing policies regarding conservation area buffer zones in Indonesia? and 2) how is the development performance of conservation area buffer zones in Indonesia?

\section{Methods}

This study is an exploratory research. Exploratory research is a type of research approach that aims to seek or formulate a particular phenomenon's problems. This research seeks to ask research questions that limit the research scope and provide new explanations for certain realities from a new perspective (Reiter, 2017). The method used to collect data in this exploratory research was a literature review with semisystematic approach to identify and understand a topic from all relevant research that has implications for the topic (Wong et al., 2013).

This study was conducted in April-September 2020. There were four steps in conducting publication searches to obtain the broadest range of available literature in the search results ( $\mathrm{Du}$ et al., 2015). Step 1 was the search for publications through Google Scholar and the IPB Repository. Selected publications were those related to the research title. The search keywords used included but were not limited to: "daerah penyangga", "buffer zone", "penyangga kawasan konservasi", and "penelitian daerah penyangga".

In Step 2, tracing publications referenced in the publications obtained in Step 1 was aimed to expand the publication search. In Step 3, a review of the publications obtained was aimed to summarize the points that were considered relevant to research questions. In Step 4, an analysis of the review results was carried out using thematic analysis. Thematic analysis is a method of analysis that identifies, analyzes, and reports patterns in the data. The themes in question are essential findings in the data, which are the answers to research questions (Braun \& Clarke, 2006).

\section{Results and Discussion}

Formal regulations on conservation area buffer zones in Indonesia According to the Law of the Republic of Indonesia (Undang-Undang Republik Indonesia/UU RI) Number 12/2011 concerning establishment of legislation, the hierarchy structure of formal regulations in Indonesia tops with the 1945 Constitution of the Republic of Indonesia (Undang-Undang Dasar Republik Indonesia Tahun 1945/UUD RI 1945) which has the most potent power of law, followed in descending order by the Decree of the People's Consultative Council (Ketetapan Majelis Permusyawaratan Rakyat/TAP MPR), UU RI and or the Government Regulation in Lieu of the Law (Peraturan Pemerintah Pengganti Undang-Undang/Perppu), the Government Regulation (Peraturan Pemerintah Republik Indonesia/PP RI), the Presidential Regulation, (Peraturan Presiden/Perpres), the Ministerial Regulation, the Provincial Regulation, and the Regional/Municipal Regulation. Since Indonesia's independence in 1945, nature conservation was initially regulated in UU RI Number 5/1967 concerning principal provisions of forestry but later specifically regulated in UU RI Number 5/1990 concerning living natural resources conservation and their ecosystems. Other formal regulations related to UU RI Number 5/1990 and or related to the management of conservation area buffer zones in Indonesia are presented in Table 1.

Article 16 and Article 29 in the Section 2 of UU RI Number 5/1990 defines a buffer zone as an area located outside a conservation forest area. The regulation states that a buffer zone could be either as other state forest areas, free state land, or land burdened with rights, which is necessary and capable of maintaining the conservation area's integrity. It also states that the management of conservation area buffer zones remains in the rightful hands; meanwhile, the management procedures still have to comply with the provisions stipulated by PP RI. One of the implementing

Table 1 Regulations concerning the management of conservation area buffer zones in Indonesia

\begin{tabular}{ll}
\hline \multicolumn{1}{c}{ Regulation } & \multicolumn{1}{c}{ Concerning } \\
\hline $\begin{array}{l}\text { The Government Regulation of the Republic of } \\
\text { Indonesia (PP RI) Number 68/1998 }\end{array}$ & $\begin{array}{l}\text { Nature reserve areas and nature conservation } \\
\text { areas }\end{array}$ \\
\hline $\begin{array}{l}\text { The Government Regulation of the Republic of } \\
\text { Indonesia (PP RI) Number 28/2011 (jo. Number } \\
108 / 2015)\end{array}$ & $\begin{array}{l}\text { Management of nature reserve areas and nature } \\
\text { conservation areas (and its amendment) }\end{array}$ \\
\hline $\begin{array}{l}\text { The Regulation of the Minister of Forestry of the } \\
\text { Republic of Indonesia (PERMENHUT) Number } \\
\text { P.67/Menhut -11/2011 }\end{array}$ & $\begin{array}{l}\text { The general guidelines for the use of working } \\
\text { capital assistance expenditures for the } \\
\text { development of conservation villages in } \\
\text { conservation area buffer zones }\end{array}$ \\
\hline $\begin{array}{l}\text { The Regulation of the Minister of Environment and } \\
\text { Forestry of the Republic of Indonesia (PERMENLHK) } \\
\text { Number P.43/MENLHK/SETJEN/KUM.1/6/2017 }\end{array}$ & $\begin{array}{l}\text { Empowerment of communities around nature } \\
\text { reserve areas and nature conservation areas }\end{array}$ \\
\hline
\end{tabular}


regulations of UU RI Number 5/1990 is PP RI Number $68 / 1998$, in which provisions concerning conservation area buffer zones are stated in Article 56 and Article 57. These articles regulate the establishment, management, and strengthening of buffer zones' functions. In this regulation, there are three provision matters considered crucial concerning conservation area buffer zones. Firstly, regarding the provision of buffer zone establishment criteria, Basuni (2003) states that the criteria would complicate the buffer zone establishment, whereby only one out of three criteria is appropriate as an establishment criterion. The other two criteria are more suitable as criteria of management performance. Secondly, regarding the establishment of conservation area buffer zones either on free state land or land burdened with rights, the provincial governors' role is limited to providing considerations to the Minister of Forestry. Lastly, the strengthening of buffer zones' functions is regulated as the authority of the central government. Hence, these three provision matters might be potentially counterproductive towards the development of conservation area buffer zones.

Related to PP RI Number 68/1998, the Ministry of Home Affairs released the Circular Letter Number $660.1 / 269 / \mathrm{V} /$ Bangda/1999 concerning the management of national park buffer zones, which was addressed to all provincial governors in Indonesia. The matters of utmost importance and urgency in this letter include the planning, organizing, executing, monitoring, evaluating, reporting, and financing the management of national park buffer zones. Due to its purpose as a means of internal communication, this letter is not considered a public law. However, this letter is deemed sufficient to convey the Ministry of Home Affairs' support on the management of conservation area buffer zones to the Ministry of Environment and Forestry.

The substance of the circular letter can be summarized as follows. In the section of the letter concerning the planning of national park buffer zones, it is stated that national park buffer zones are established by formal regulations with the provisions, namely: 1) if a national park buffer zone is located in one regency, it is established by regional/municipal regulation; 2) if a national park buffer zone is located in more than one regency, it is established by provincial regulation, and 3) if a national park buffer zone is located in more than one province, it is established by the regulation of the ministry of home affairs. In the organizational aspect, the circular letter states the hierarchical organization structure in the buffer zone management consists of buffer zone management coordination team at the central government level until the sub-district or village level, including the respective roles and responsibilities of each level of coordination team. The management of conservation area buffer zones is carried out by organizations, agencies, and or institutions which have programs and activities in national park buffer zones and are presumed to be able to manage them in an integrated manner. Monitoring is conducted hierarchically on each government level; buffer zone management coordination team at the central government level monitors the team at the provincial and regional/municipal level and the team at the provincial level monitors the team at the regional/municipal and district level, and so forth. Meanwhile, the financing source of conservation area buffer zones' management might be from Local Government Budget (Anggaran Pendapatan dan Belanja Daerah/APBD) at the provincial and regional/municipal level, state budget, foreign aids, and or other legal sources.

Thirteen years since the promulgation of PP RI Number $68 / 1998$, there have only been 3 conservation areas in Indonesia with a buffer zone formally established with provincial or regional/municipal regulation(s) (Table 2). The poor performance of the development of conservation area buffer zones, the existence of the Circular Letter of the $\mathrm{Minister}$ of $\mathrm{Home}$ Affairs $\mathrm{Number}$ $660.1 / 269 / \mathrm{V} /$ Bangda/1999, as well as numerous research publications concerning buffer zone development, drove the promulgation of PP RI Number 28/2011 to replace PP RI Number 68/1998. While in PP RI Number 68/1998 there are only 2 articles that regulate conservation area buffer zones, PP RI Number 28/2011 contains 4 articles. There are two provision matters in PP RI Number 28/2011 that are considered to be able to accelerate the development of conservation area buffer zones in Indonesia. Firstly, PP RI Number 28/2011 states that the areas of a buffer zone which lie outside protected or production forests could be formally

Table 2 List of conservation areas in Indonesia that already had buffer zone formally established by provincial or regional government

\begin{tabular}{ll}
\hline \multicolumn{1}{c}{ Conservation area } & \multicolumn{1}{c}{ Regulation } \\
\hline Berbak National Park & The Decree of the Governor of Jambi Number 320/1999 \\
Gunung Palung National Park & The Decree of the Regent of Ketapang Number 173/2002 \\
Lore Lindu National Park & The Regional Regulation of Central Sulawesi Number 6/2006 \\
$\begin{array}{l}\text { Lembah Anai Strict Nature Reserve and } \\
\text { Megamendung Nature Recreation Park }\end{array}$ & The Decree of the Governor of West Sumatera Number 99/2012 \\
Ujung Kulon National Park & The Regional Regulation of District of Pandeglang Number 2/2013 \\
$\begin{array}{l}\text { Pamona Strict Nature Reserve and } \\
\text { Bancea Nature Recreation Park }\end{array}$ & The Decree of the Regent of Poso Number $188.45 / 1351 / 2015$ \\
Cycloops Strict Nature Reserve & The Regional Regulation of Jayapura Regency Number 9/2015 and The \\
& Regional Regulation of Jayapura City Number 6/2016 \\
\hline
\end{tabular}


established as a buffer zone with the povincial regulation or regional/municipal regulation according to their authority. Secondly, this regulation omits the criteria of buffer zone establishment. Moreover, PP RI Number 28/2011 also provides more detailed provisions concerning conservation area buffer zones' management. It states that the central and regional governments must manage conservation area buffer zones by forming buffer zone management plans, rehabilitating, utilizing, protecting, guarding, and strengthening the functions of buffer zones. The management plan of buffer zones is regulated to refer to the management plan of their respective conservation area and regional development plan. Meanwhile, the scope of the strengthening of buffer zones' functions includes improving the local communities' comprehension concerning the conservation of living natural resources and their ecosystems, enhancing the local communities' knowledge and skills to improve their welfare, and increasing land productivity. Regarding land ownership, Article 46 of PP RI Number 28/2011 states that the management of buffer zones on land burdened with rights is carried out by the right holders with consistently taking into account the overall buffer zone management plan.

Nevertheless, the latest provisions of conservation area buffer zones in PP RI Number 28/2011, as explained above, are still insufficient to provide more opportunities for participatory process and gain the crucial support of provincial and regional/municipal governments. This insufficiency is evident in the slight increase of the number of conservation areas with a formally established buffer zone since PP RI Number 28/2011. Up to 2020, there have been only 6 additions to the list (Table 2). According to Basuni (2016), the number of conservation area units in Indonesia is 530 units. Out of those, there are only a total of nine (1.7\%) conservation areas with a formally established buffer zone. Therefore, it is assumed that both PP RI Number 68/1998 and PP RI Number 28/2011 create a condition of internally locked institutions so much so withholding a cluster of institutional development opportunities at the provincial and regional/municipal level of the buffer zone management.

In PP RI Number 68/1998, the locking presents within two provision matters. Firstly, the locking presents in the provision that regulates the minister of forestry's authority to establish buffer zones in non-forest area lands; meanwhile, the provincial governors' role is limited to providing considerations. Secondly, it also presents in the provision in which the central government is the only authoritative body to carry out the strengthening of buffer zones' functions (Basuni, 2003). Meanwhile, in PP RI Number 28/2011, the locking presents in Article 47 that states the procedures of establishing and managing buffer zones are provisioned by the regulation of the minister of forestry, without mentioning whether the buffer zones to be regulated are located in forest area or not. Whereas the establishment of buffer zones in nonforest areas is under the authority of provincial governors, regents, or mayors following their respective jurisdiction as provisioned in Article 45.

Since the promulgation of PP RI Number 68/1998 and PP RI Number 28/2011, there have only been 2 regulations of the ministry of forestry concerning buffer zones. Firstly, the
Regulation of the Minister of Forestry of the Republic of Indonesia (PERMENHUT) Number P.67/Menhut-11/2011 concerning the general guidelines for the use of working capital assistance expenditures for the development of conservation villages in conservation area buffer zones. This regulation explicitly regulates that the capital assistance for conservation villages development in conservation area buffer zones is aimed to run community empowerment programs proposed and managed by the technical implementing units under the Directorate General of the Conservation of Natural Resources and Their Ecosystems (Konservasi Sumber Daya Alam dan Ekosistemnyal KSDAE), a directorate general in the ministry of environment and forestry. Secondly, the Regulation of the Minister of Environment and Forestry of the Republic of I n d o n e s i a ( P E R M E N L H K ) N u m b e r P.43/MENLHK/SETJEN/KUM.1/6/2017 concerning empowerment of communities around nature reserve areas and nature conservation areas. This regulation does not explicitly regulate conservation area buffer zones. It only defines community empowerment programs' actors and targets, namely conservation area managers, community groups, as well as village heads and their apparatus. Instead of providing more opportunities for forming buffer zone institutions at the provincial and regional/municipal level, these two ministerial regulations also create a condition of internally locked institutions.

Since the promulgation of PP RI Number 68/1998, the management of buffer zones has focused more on strengthening the functions of buffer zones in the form of projects of the central government carried out by the technical implementing units of the directorate general of KSDAE. Therefore, several decrees and regulations of director generals have been issued to support the strengthening of the functions of buffer zones, namely the Decree of the Director General of the Forest Protection and Nature Preservation (Perlindungan Hutan dan Pelestarian Alam/PHPA) Number 44/Kpts/DJ-VI/1997 concerning the technical instructions for the formation of the buffer zone development design, the Decree of the Director General of PHPA Number 49/Kpts/DJ-VI/1997 concerning the technical instructions for buffer zone development, the Regulation of the Director General of the Forest Protection and Nature Conservation (Perlindungan Hutan dan Konservasi Alam/PHKA) Number SK 203/IVKKBHL/2012 concerning the technical guidelines for community empowerment in conservation area buffer zones, the Regulation of the Director General of PHKA Number SK 204/IV-KKBHL/2012 concerning the technical guidelines for monitoring and evaluation of community empowerment in conservation area buffer zones, and the Regulation of the Director General of KSDAE Number P.6/KSDAE/SET/Kum.1/6/2018 concerning the technical guidelines for conservation partnerships in nature reserves areas and nature conservation areas. The decrees and regulations of the director generals are not public laws and only apply within their respective institutions. Therefore, their existence only exacerbates the condition of internally locked institutions. Nevertheless, the projects for strengthening the functions of buffer zones have attracted 
much interests from researchers.

Research related to buffer zones Since the promulgation of regulations concerning the conservation area buffer zones in Indonesia, research on various topics concerning buffer zones has been conducted (Table 3). The search for research publications through Google Scholar and the IPB Repository results in 81 research publications concerning conservation area buffer zones in Indonesia. In need of identifying and analyzing the problems in the management of buffer zones, these research publications are grouped into 5 research topics: biophysical aspect; social, economic, and cultural aspects; management aspect; conservation village model program; and ecotourism.

Management aspect and social, economic and cultural aspects become the two most researched topics with the number of publications amount to 26 and 24 publications respectively. Among all categories of conservation areas, national park (taman nasional) buffer zones are the most researched category with 72 publications, followed by the number of publications on the buffer zone of strict nature reserves area (cagar alam) which amounts to three publications. Meanwhile, the amount of research publications for either buffer zones of nature recreation park (taman wisata alam), grand forest park (taman hutan raya), and hunting park (taman buru) is one publication and no record of research publication on wildlife reserve (suaka margasatwa) buffer zones. The management aspect becomes the most researched topic might be due to the complexity of the relationship between the natural resources' characteristics and the local communities' social characteristics. This relationship is a consequence of the various potential functions and benefits of the buffer zones and a diversity of stakeholders that require policies and institutions which can support effective management (Ostrom, 2005). Meanwhile, social, cultural, and economic aspects become another most researched topic might be due to the various topics the researchers could study in those aspects. Another cause of this phenomenon might be the considerable attention towards buffer zones' ability to support conservation efforts as well as improve local community welfare (Martino, 2001). The comparably higher number of research publications on national park buffer zones might be due to the more intensive management and the higher number of projects for strengthening national park buffer zones' functions than other categories of conservation area. This condition provides more opportunities that encourage more initiatives and innovations in national parks' management. However, it is necessary to assume that conservation areas other than national parks need more innovations in their management, considering they receive more pressure and disturbances than national parks. Gunningham et al. (1998) argue that the complexity of social, economic, and ecological process renders general and straightforward solutions impossible in resolving environmental problems. Generalized policies would be inferior to the ones based on a case-by-case analysis. Therefore, researchers should research buffer zone management in Indonesia's conservation areas, either the existing or future ones. Furthermore, research on the implementation of the buffer zone concept in every category of conservation area in each bioregion in Indonesia needs to be conducted to create sustainability of adaptive patterns, evaluations, and improvement.

The grouping of research publications obtained based on the bioregion shown that research on conservation area buffer zones had been mainly conducted in Java and Sumatera Island (Figure 1). It is a predictable result considering that Java and Sumatra Island have historically been the centre of development in Indonesia which causes rapid population growth and forest land conversion, hence prompted the Indonesian government to designate and establish conservation areas. The continuous and increasingly rapid development on these two islands also creates a concentration of information and technology, primarily in Java Island, which is also the island where the Indonesian government's centre is located.

The management of buffer zones The research publications on the biophysical aspect of conservation area buffer zones show that formal establishment of buffer zones is necessary to direct a form of management that supports biodiversity protection, particularly wildlife that uses buffer zones as their habitat (Salafsky, 1993; Suprapto, 2000; Suyanto \& Semiadi, 2004; Prasetyo \& Sugardjito, 2010; Irni, 2017; Mahyudi, 2017; Nurmaeti et al., 2018), and prevents or stops forest land conversion and deforestation (Alkaf, 2014; Nurrani et al., 2014; Handoyoseputro, 2018; Kurniawan et al., 2018). Moreover, the research results could also be used

Table 3 The number of research publications on conservation area buffer zones in Indonesia

\begin{tabular}{lccccc}
\hline & \multicolumn{5}{c}{ Research topic } \\
\cline { 2 - 6 } Form of publications & $\begin{array}{c}\text { Biophysical } \\
\text { aspect }\end{array}$ & $\begin{array}{c}\text { Social, cultural, and } \\
\text { economic aspects }\end{array}$ & $\begin{array}{c}\text { Management } \\
\text { aspect }\end{array}$ & $\begin{array}{c}\text { Conservation village } \\
\text { model program }\end{array}$ & Ecotourism \\
\cline { 2 - 6 } & 5 & 11 & 2 & 3 & 1 \\
\hline Undergraduate thesis & 4 & 3 & 5 & 1 & 2 \\
Master thesis & 0 & 2 & 3 & 1 & 0 \\
Dissertation & 7 & 8 & 16 & 6 & 1 \\
Article in journal & 16 & 24 & 26 & 11 & 4
\end{tabular}


as the medium to build shared understanding and local community participation in managing buffer zones (Bagja, 2000; Mahalia, 2000; Hervianti, 2001; Muliana, 2001). The use of technology could improve the process of obtaining information needed in buffer zone management, such as information on biological resources and land cover changes.

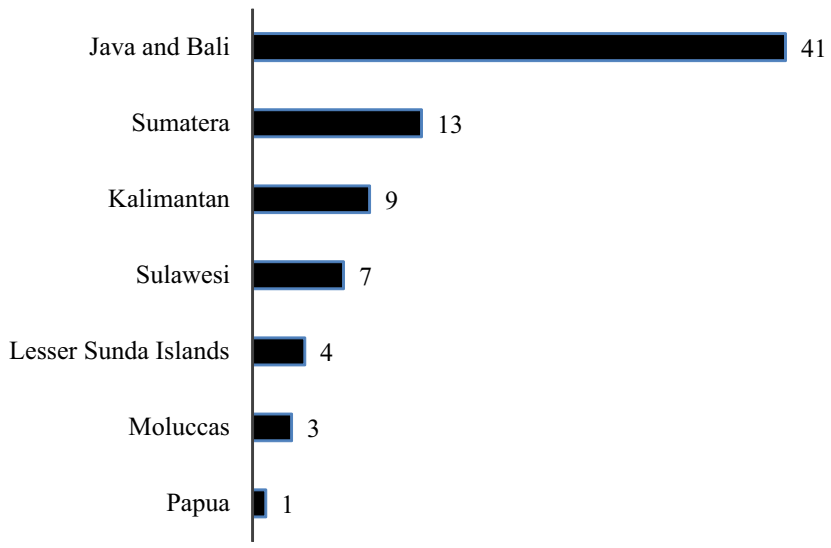

Figure 1 Number of research publications on conservation area buffer zones based on the bioregion.
This information is crucial in planning, monitoring, and evaluating the management of buffer zones. Meanwhile, several other research publications have offered recommendations regarding buffer zones' types or models (Table 4).

Numerous research publications that recommend the types or models of buffer zones indicate that the researched conservation area buffer zones have not yet been definitive and formally established. Nevertheless, the recommendations offered in these research publications would be beneficial after the formal establishment of the conservation area buffer zones, at least as substantial considerations in making the buffer zone management plan as mandated in PP RI Number 28/2011. Moreover, for the design of the type or model of buffer zones to be functional, all stakeholders must participate in the process, particularly the landowners. The participatory process provides the possibilities and opportunities to resolve every disagreement through consensus built throughout the management process (Beaumont, 1997; Ervin et al., 2010).

The strengthening of buffer zones' functions Community empowerment is one of the many approaches used to strengthen buffer zones' functions as mandated in PP RI Number 28/2011 and the Circular Letter of the Minister of

Table 4 Research on buffer zone's types or models

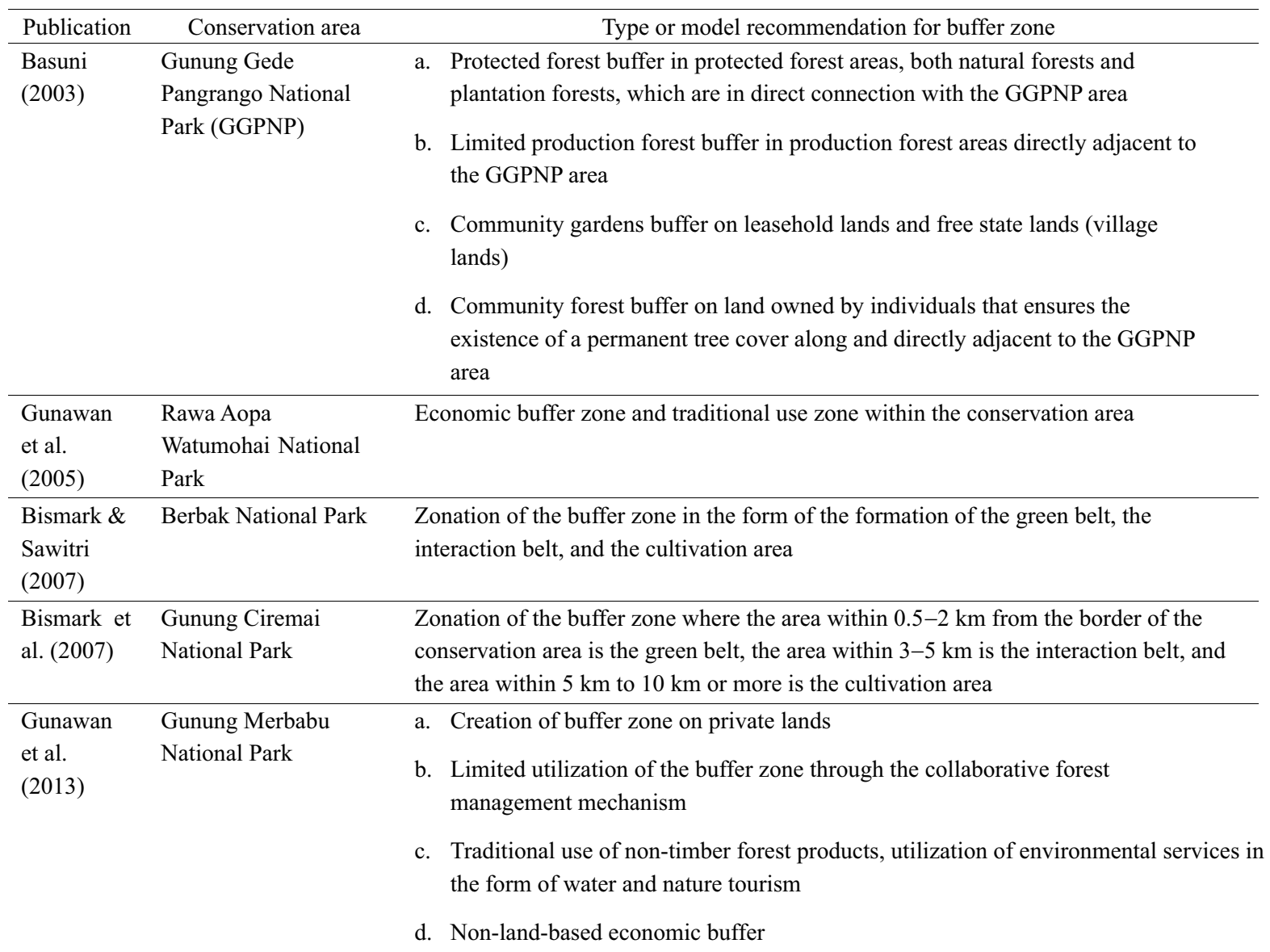


Home Affairs Number 660.1/269/V/Bangda/1999. The result of the review of research publications on the social, cultural, and economic aspects of buffer zones; conservation village model program; and ecotourism shows that communities' dependence on land resources is still relatively high, particularly the indigenous communities (Gunawan et al., 2013; Adalina, 2014). Therefore, land-based community empowerment programs need to be a concern, especially regarding land tillage.

Socio-demographic characteristics, local communities' interaction with and access to resources, and approaches used in the programs are some factors that influence the success of either land-based or non-land-based community empowerment programs (Ristianasari, 2013). Meanwhile, Tucker (2010) argues that land-based community empowerment programs need to be supported by guaranteeing land rights as an enabling condition for sustainability. On the other hand, most of non-land-based community empowerment programs already carried out in various buffer zones have not yet demonstrated the ability to improve local community welfare in a sustainable manner (Handasari, 2013; Maysarah, 2017). Non-land-based community empowerment programs are still focused on reducing communities' dependence on forest and land resources, among others, through livestock grants and training in the processing of crops. However, building empowered communities requires other capacities, including financial management and marketing (Mulpiadi et al., 2014; Fadillah, 2019). Furthermore, assistance for communities in carrying out community empowerment programs needs to be conducted intensively, particularly in improving social capital, which is essential for the sustainability of the programs (Suciyanto, 2008; Tobing, 2008; Effendi et al., 2014; Pratidina, 2014; Ichsan, 2017). Community empowerment programs based on ecosystem services utilization also need to be a priority due to ecosystem services' sustainability depending on forest functions' sustainability. Moreover, ecosystem services are also considered to attract a large market (Kurniawan, 2012; Silori, 2015; Andriyanningsih, 2019).

The institutions of buffer zones The result of the review of research publications on the institutional aspect of buffer zones shows that institutions affect the implementation of the buffer zone concept in terms of providing clarity for stakeholders' rights and obligations. The clarity of rights and obligations could improve local communities' social capital (Savioli \& Patuelli, 2016), which would support the management of buffer zones capable of realizing their potential functions and benefits sustainably.

Explicit provisions of property rights, jurisdictional boundary, and rule of representations could be some aspects to be improved in buffer zone institutions (Basuni, 2003). The improvement could also be in recognizing the right of local communities to participate in the buffer zone management. This recognition is also a form of rights transfer from the government, which can reduce the implementation and monitoring (policing) costs of the buffer zone management (Khalik, 2007). Furthermore, the recognition also creates community legitimacy in mutually agreed institutions.
Meanwhile, Ichsan's study in Gunung Rinjani National Park (2017) shows the importance of empowering local community groups in the formation process of buffer zone institutions. Moreover, enhancement in local communities' organizational capacities and leadership that can support the local institutions' strengthening need to be a part of community empowerment programs (Suyadi, 2018). In regards to community empowerment, Ichsan (2017) also highlights the PERMENLHK Number P.7/Menlhk/Setjen/OTL.0/1/2016 concerning the organization and work procedure of the national park technical implementing unit which has not yet assigned a particular structure within the organization of national park offices to manage community empowerment programs specifically. This provision has also not yet been in accordance with the PERMENLHK Number P.74/Menlhk/Setjen/Kum.1/8/2016 concerning the guidelines for the nomenclature of provincial and regional/municipal apparatus implementing government affairs in the environmental sector and government affairs in the forestry sector. The latter regulates a particular subsector/division assigned under the provincial forestry service is responsible for assisting community empowerment programs. A similar situation also occurs with the Regional Planning and Development Agency (Badan Perencanaan dan Pembangunan Daerah/BAPPEDA) and the Regional Environmental Impact Management Agency (Badan Pengendalian Dampak Lingkungan Daerah/BAPEDALDA). These two institutions have not yet coordinated the implementation of buffer zone management as mandated in the Circular Letter of the Minister of Home Affairs Number 660.1/269/V/Bangda/1999. The arguments of the need for more personnel to assist the community empowerment programs in various research publications strongly suggest that a particular structure is vital to be assigned in the technical implementing units of the directorate general of KSDAE and provincial or regional/municipal government that is focused on the community empowerment issues at the site level.

\section{Conclusion}

There have only been nine out of $530(1.7 \%)$ conservation area units in Indonesia with a formally established buffer zone. Meanwhile, the management of conservation area buffer zones in Indonesia has only been carried out through various projects for strengthening the functions of buffer zones by conservation area managers in the form of land-based and non-land-based programs. The poor performance of the management of buffer zones is mainly due to internally locked institutions within the central government level (the Ministry of Environment and Forestry) so much so withholding opportunities to build participatory process and gain strong institutional support from provincial and regional/municipal governments.

\section{Recommendation}

This study results in recommendations for all interested parties to urge The Ministry of Environment and Forestry to stipulate ministerial regulation concerning the procedures of establishing and managing conservation area buffer zones as 
mandated in Article 47 of PP RI Number 28/2011. The other option is to urge the government to amend Article 47 of PP RI Number 28/2011 jo. PP RI Number 108/2015 thus only regulating the procedures of the establishment of conservation area buffer zones on forest areas. It is also crucial to urge the Ministry of Home Affairs to replace the Circular Letter of the Minister of Home Affairs Number $660.1 / 269 / \mathrm{V} /$ Bangda/1999 concerning the management of national park buffer zones with a ministerial regulation concerning the establishment and management of conservation area buffer zones. In the institutional aspect of the buffer zone management, it is necessary to assign a particular structure in the technical implementing units of the directorate general of KSDAE and provincial or regional/municipal government that is focused on the community empowerment issues at the site level. There is also a need to increase land-based community empowerment programs, particularly on land tillage, and non-land-based programs such as empowering local community groups and indigenous communities.

\section{References}

Adalina, Y. (2014). Implikasi modal sosial masyarakat terhadap pengelolaan taman nasional (Studi kasus Taman Nasional Gunung Halimun Salak) [dissertation]. Bogor: Institut Pertanian Bogor.

Alkaf, M. (2014). Analisis perubahan penggunaan lahan dan arahan pemanfaatan lahan di Taman Nasional Gunung Merbabu serta daerah penyangganya [thesis]. Bogor: Institut Pertanian Bogor.

Andriyanningsih, S. (2019). Perubahan sikap dan perilaku masyarakat desa penyangga Taman Nasional Gunung Ciremai Jawa Barat [undergraduate thesis]. Bogor: Institut Pertanian Bogor.

Bagja, B. (2000). Aplikasi sistem informasi geografis dalam penentuan status pemenuhan kebutuhan kayu bakar di daerah penyangga Taman Nasional Gunung Gede Pangrango (Studi kasus di Desa Galudra dan Sukamulya, Kecamatan Cugenang, Kabupaten Cianjur) [undergraduate thesis]. Bogor: Institut Pertanian Bogor.

Basuni, S. (2003). Inovasi institusi untuk meningkatkan kinerja daerah penyangga kawasan konservasi (Studi kasus di Taman Nasional Gunung Gede Pangrango, Jawa Barat) [dissertation]. Bogor: Institut Pertanian Bogor.

Basuni, S. (2016). Buku orasi ilmiah Guru Besar IPB: Landasan filosofis, teori, dan praktik konservasi biodiversitas di Indonesia. Bogor: Institut Pertanian Bogor.

Beaumont, J. (1997). Community participation in the establishment and management of marine protected areas: A review of selected international experience. South African Journal of Marine Science, 7615(18), 333-340. https://doi.org/10.2989/025776197784161009

Bismark, M., \& Sawitri, R. (2007). Pengembangan dan pengelolaan daerah penyangga kawasan konservasi. In M. Bismark (Ed.), Prosiding ekspose hasil-hasil penelitian: Konservasi dan rehabilitasi sumberdaya alam (pp. 1-11). Padang: Badan Penelitian dan Pengembangan Kehutanan, Pusat Penelitian dan Pengembangan Hutan dan Konservasi Alam, Departemen Kehutanan.

Bismark, M., Sawitri, R., \& Eman, E. (2007). Pengelolaan dan zonasi daerah penyangga Taman Nasional Gunung Ciremai, Kabupaten Kuningan, Jawa Barat. Jurnal Penelitian Hutan dan Konservasi Alam, 4(5), 467-483. https://doi.org/10.20886/jphka.2007.4.5.467-483

Braun, V., \& Clarke, V. (2006). Using thematic analysis in psychology. Qualitative Research in Psychology, 3(2), 77-101. https://doi.org/10.1191/1478088706qp063oa

Du, W., Penabaz-Wiley, S. M., Njeru, A. M., \& Kinoshita, I. (2015). Models and approaches for integrating protected areas with their surroundings: A review of the literature. Sustainability, 7(7), 8151-8177. https://doi.org/10.3390/ su7078151

Ebregt, A., \& Greve, P. de. (2000). Buffer zones and their management: Policy and best practices for terrestrial ecosystems in developing countries. Wageningen: National Reference Centre for Nature Management (ECLNV) and International Agricultural Centre (IAC). Retrieved from http://edepot.wur.n1/ 118089\%0Apapers2://publication/uuid/AE1F55C82066-4DCC-B28F-577EB8F78094

Effendi, A. D., Barkey, R. A., \& Jamil, M. H. (2014). Strategi pengembangan program pemberdayaan masyarakat pada model desa konservasi di Taman Nasional Taka Bonerate. Jurnal Sains \& Teknologi, 14(2), 151-161.

Ervin, J., Mulongoy, K. J., Lawrence, K., Game, E., Sheppard, D., Bridgewater, P., ..., \& Bos, P. (2010). Making protected areas relevant: A guide to integrating protected areas into wider landscapes, seascapes and sectoral plans and strategies. CBD Technical Series No. 44. Montréal: Convention on Biological Diversity, 94pp.

Fadillah, F. (2019). Implementasi program model desa konservasi (MDK) di Taman Wisata Alam (TWA) Lejja. Jurnal Pendidikan Teknologi Pertanian, 5(2), 27-34.

Gunawan, H., Allo, M., Putri, I., Qiptiyah, M., \& Rakhman, M. (2005). Model zona penyangga Taman Nasional Rawa Aopa Watumohai di Provinsi Sulawesi Tenggara. Jurnal Penelitian Hutan dan Konservasi Alam, 2(5).

Gunawan, H., Bismark, M., \& Krisnawati, H. (2013). Kajian sosial ekonomi masyarakat sekitar sebagai dasar penetapan tipe penyangga Taman Nasional Gunung Merbabu, Jawa Tengah. Jurnal Penelitian Hutan dan Konservasi Alam, 10(2), 103-119.

Gunningham, N., Grabosky, P., \& Sinclair, D. (1998). Smart regulation: Designing environment policy. 
Gloucestershire: Clarendon Press.

Handasari, I. (2013). Pengelolaan resolusi konflik agraria kawasan Taman Nasional Gunung Gede Pangrango: Sikap dan strategi bertahan [undergraduate thesis]. Bogor: Institut Pertanian Bogor.

Handoyoseputro, K. (2018). Analisis penggunaan lahan dan arahan pengelolaan di Taman Nasional Gunung Maras dan area penyangganya [thesis]. Bogor: Institut Pertanian Bogor.

Hervianti, M. R. (2001). Peranan sub sektor produksi tanaman pangan di daerah penyangga Taman Nasional Gunung Gede Pangrango (Studi kasus di Resort Bodogol, Resort Cimande, Resort Goalpara dan Resort Selabintana) [undergraduate thesis]. Bogor: Institut Pertanian Bogor.

Ichsan, A. C. (2017). Kelembagaan model desa konservasi di Taman Nasional Gunung Rinjani Provinsi Nusa Tenggara Barat [dissertation]. Bogor: Institut Pertanian Bogor.

Irni, J. (2017). Keanekaragaman jenis kupu-kupu dan desain pemanfaatannya sebagai Taman Kupu-Kupu di kawasan penyangga Tangkahan Taman Nasional Gunung Leuser [thesis]. Bogor: Institut Pertanian Bogor.

Khalik, I. (2007). Analisis kelembagaan pengelolaan daerah penyangga Taman Nasional Kerinci Seblat (Studi kasus di Eks HPH PT Maju Jaya Raya Timber Kabupaten Bengkulu Utara Provinsi Bengkulu) [thesis]. Bogor: Institut Pertanian Bogor.

Kurniawan, I., Barus, B., \& Pravitasari, A. E. (2018). Pemodelan spasial perubahan penggunaan lahan di Taman Nasional Gunung Halimun Salak dan daerah penyangganya. Journal of Regional and Rural Development Planning, 1(3), 270. https://doi.org/ 10.29244/jp2wd.2017.1.3.270-286

Kurniawan, W. (2012). Konsep pemberdayaan masyarakat dalam penyelesaian konflik lahan di Taman Nasional Gunung Halimun Salak [dissertation]. Bogor: Institut Pertanian Bogor.

Mahalia. (2000). Kapasitas sangga sub sektor produksi tanaman keras di daerah penyangga Taman Nasional Gunung Gede Pangrango Jawa Barat (Studi kasus di Resort Bodogol, Resort Cimande, Resort Goalpara dan Resort Selabintana) [undergraduate thesis]. Bogor: Institut Pertanian Bogor.

Mahyudi, I. (2017). Kajian potensi iktiofauna di kawasan penyangga Resort Suo-Suo Taman Nasional Bukit Tigapuluh [thesis]. Bogor: Institut Pertanian Bogor.

Martino, D. (2001). Buffer zones around protected areas: A brief literature review. Retrieved from https:/escholarship.org/uc/item/02n4v17n

Maysarah, D. (2017). Kesejahteraan ekonomi masyarakat daerah penyangga Taman Nasional Gunung Gede Pangrango [undergraduate thesis]. Bogor: Institut Pertanian Bogor.

Muliana, D. (2001). Kapasitas sangga sub sektor produksi peternakan di daerah penyangga Taman Nasional Gunung Gede Pangrango Propinsi Jawa Barat (Studi kasus di Resort Bodogol, Resort Cimande, Resort Goalpara, Resort Selabintana, dan Resort Cibodas) [undergraduate thesis]. Bogor: Institut Pertanian Bogor.

Mulpiadi, Soetoro, \& Hardiyanto, T. (2014). Respon petani terhadap kegiatan model desa konservasi (MDK) di kawasan Taman Buru Masigit Kareumbi (Studi kasus pada kelompok MDK di Desa Sindulang Kecamatan Cimanggung Kabupaten Sumedang). AGRO INFO GALUH, 2(1), 35-40.

Nurmaeti, C., Abidin, Z., \& Prianto, A. (2018). Keanekaragaman burung pada zona penyangga Taman Nasional Gunung Ciremai. Quagga: Jurnal Pendidikan Dan Biologi, 10(2), 54. https://doi.org/10.25134/ quagga.v10i2.1297

Nurrani, L., Bismark, M., \& Tabba, S. (2014). Tipologi penggunaan lahan oleh masyarakat pada zona penyangga Taman Nasional Aketajawe Lolobata di Kabupaten Halmahera Timur. Jurnal Penelitian Sosial dan Ekonomi Kehutanan, 11(3), 223-235. https://doi.org/10.20886/ jsek.2014.11.3.223-235

Ostrom, E. (2005). Understanding institutional diversity . New Jersey: Princeton University Press. Retrieved from https://www.academia.edu/8012441/_Elinor_Ostrom_ Understanding_Institutional_Diversity

Prasetyo, D., \& Sugardjito, J. (2010). Status populasi satwa primata di Taman Nasional Gunung Palung dan daerah penyangga, Kalimantan Barat. Jurnal Primatologi Indonesia, 7(2), 60-68.

Pratidina, G. (2014). Penerapan kebijakan model kampung konservasi taman nasional. Jurnal Ilmu Administrasi Negara, 12(4), 256-266.

Reiter, B. (2017). Theory and methodology of exploratory social science research. Ijsrm. Human, 5(54), 129-150. Retrieved from https://scholarcommons.usf.edu/ cgi $/$ viewcontent.cgi? article $=1134 \&$ context $=$ gia_facpub

Ristianasari. (2013). Efektifitas pemberdayaan masyarakat di Taman Nasional Bukit Barisan Selatan (TNBBS): Kasus model desa konservasi (MDK) di Pekon Sukaraja dan Pekon Kubu Perahu, Lampung [thesis]. Bogor: Institut Pertanian Bogor.

Salafsky, N. (1993). Mammalian use of a buffer zone agroforestry system bordering Gunung Palung National Park, West Kalimantan, Indonesia. Conservation Biology, 7(4), 929-933.

Savioli, M., \& Patuelli, R. (2016). Social capital, institutions 
and policymaking. Quaderni-Working Paper DSE $\mathrm{N}^{\circ} 1070$. Retrieved from https://doi.org/10.2139/ ssrn.2792161

Sayer, J. (1991). Rainforest buffer zones: Guidelines for protected area managers. The International Union for Conservation of Nature and Natural Resources. Retrieved from https://portals.iucn.org/library/sites/library/files/ documents/FR-001.pdf

Silori, C. S. (2015). Ecosystem services and sustainable development. In M. Sundriyal \& V. K. Dhaundiyal (Eds.), Ecosystem services and its mainstreaming in development planning process (pp. 22-32). Dehradun: Uttarakhand Science Education and Research Centre (USERC) \& Bishen Singh Mahendra Pal Singh. https://doi.org/10.1007/978-3-319-63951-2_423-1

Suciyanto, N. (2008). Evaluasi desa model di Taman Nasional Ujung Kulon (Studi kasus Desa Tamanjaya) [undergraduate thesis]. Bogor: Institut Pertanian Bogor.

Suprapto. (2000). Gangguan satwaliar mamalia besar dan nilai kerugiannya di daerah penyangga Taman Nasional Gunung Gede Pangrango Jawa Barat [undergraduate thesis]. Bogor: Institut Pertanian Bogor.
Suyadi. (2018). Kepemimpinan tokoh informal dalam peningkatan kapasitas petani agroforestri di lingkungan Taman Nasional Gunung Ciremai [dissertation]. Bogor: Institut Pertanian Bogor.

Suyanto, A., \& Semiadi, G. (2004). Keragaman mamalia di sekitar daerah penyangga Taman Nasional Gunung Halimun, Kecamatan Cipanas, Kabupaten Lebak. Berita Biologi, 7(1), 87-94.

Tobing, I. (2008). Manajemen kawasan dalam upaya konservasi sumberdaya alam hayati. VIS VITALIS, 1(2), 63-70.

Tucker, C. M. (2010). Learning on governance in forest ecosystems: Lessons from recent research. International Journal of the Commons, 4(2), 687. https://doi.org/ 10.18352/ijc.224

[UNESCO] United Nations Educational, Scientific and Cultural Organization. (1996). Biosphere reserves: The seville strategy and the statutory framework of the world network. Paris: UNESCO.

Wong, G., Greenhalgh, T., Westhorp, G., Buckingham, J., \& Pawson, R. (2013). RAMESES publication standards: Meta-narrative reviews. Journal of Advanced Nursing, 69(5), 987-1004. https://doi.org/10.1111/jan.12092 